70 卷 691 号 $(2004$ 3)

\title{
波力発電における軸流タービンの有効性に関する検討*
}

\author{
植杰圭承

\section{Efficiency of Axial-flow Turbine in a Wave Power Generation System}

\author{
Keiichi UEKI*2 \\ ${ }^{* 2}$ Research and Development Center, Tohoku Electric Power Co., Inc. \\ 721 Nakayama, Aoba ku, Sendai shi, Miyagi, 981-0952 Japan
}

\begin{abstract}
The main type of wave power generation system now in use is the oscillating water column type. Most wave power generation systems of this type use the Wells turbine. The Wells turbine, however, is a low efficiency turbine. A non Wells turbine wave power generation system has been needed because of the bidirectional airflows of the break out of the surf and the backwash. An experiment regarding the practical use of an axial flow turbine in a wave power generation system has been performed at the Haramachi site continuously since 1996. This paper presents a summary of the efficiency of the axial flow turbine in a wave power generation system.
\end{abstract}

Key Words: Wave, Blade, Valve, Energy Conversion, Marine Structures, Axial-flow Turbine, Wells Turbine, Wave Power (ieneration System, Bidirectional Air-flows

\section{1.}

振動水柱型に属する波力発電システムは, 波の水面 上下動を利用し, 空気エネルギー（空気流）に変換す ることでタービンを回転させ発電する．この波による 空気流は, 寄せ波と引き波で逆方向の往復空気流とな るため, 波力発電では往復空気流で一方向に回転する ウエルズタービン (1) が主として採用されているが, 自己起動性に乏しく，効率が低い等の課題が指摘され ている(2).

一方, 蒸気タービン等で広く使われる軸流タービン は, 定常流で効率の高いタービンであるが, 波力発電 に採用する場合，その翼形状から往復空気流を一方向 に整流する整流装置（整流弁等）が必要であると考え られていた.このため, 波力発電船「海明」では, フ ラップ弁と呼ばれる機械式整流弁を用いた実海域実験 を行ったが，大波浪時に弁体自体か吹き飛ばされる等 の弁体破損が発生している.

* 原稿曼付 2003 位 2 月 14 11

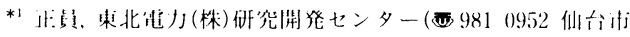

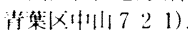

E mail : w8506013 (a tohoku epco.co.jp
この整流弁の破損により，軸流タービンを採用した 波力発電システムは, 長期発電不能となることか望念 されたことから, 波力発電用タービンとしてはウエル ズタービンが有利であるとされてきた.

波力発電では, このタービンに関する技術的な課題 の他に, 発電コス卜低減という実用化の鍵を握る大き な課題が存在する. 波力発電の設備は, 空気室等が大 掛かりなコンクリート製の港湾構造物であるため現地 施工が多く, 風車・太陽電池のように生産数増加で安 価となる要素が少なく，大幅なコスト低減は期待でき ない.このため, 現時点における発電コスト低減策と しては, 発電システムの平均発電効率を上げ，年間発 電電力量を増加させることが有効であると考えられて いる.

この発電システムの平均発電効率向上には, タービ ン効率を向上させることが効果的であると考えられる が, ウエルズタービンでは大幅な効率向上が難しいこ とから，近年になって，軸流タービンに対する期待が 再び高まり軸流夕ービン翼に関する室内実験が行われ， その優れた起動性を始めとした諸特性の報告 (2) もな されている. 
以上に述べたことから，軸流タービンが発電コスト 低減やウエルズタービンの抱える課題の解決に期待が 持てるが, 実海域実験例が少ない。そこで，今回の実 験設備では，この実海域実験例の少ない軸流夕ービン を採用することによって, 軸流夕一ビンの波力発電へ の適用可能性と有効性を確認することとした。なお， 軸流夕一ビンの採用にあたっては，今まで整流弁が必 要であると考えられていたことから，「水弁」と呼ば れる機械式弁のように致命的な破損の恐れが無い流体 を利用した整流弁を開発して採用している。

本論文では，この波力発電実験設備で行った様々な 実海域実験から，タンデム配置した軸流タービンに関 する実験結果とこれに基づき検討した内容について報 告する。

\section{2. 主な 毁 奇}

$A_{T}:$ タービン静翼スロート面積 $\left(\mathrm{m}^{2}\right)$

$C_{0}:$ 逆圧時に軸流タービン動翼出口側から流入

する逆方向流れの空気流絶対速度

$C_{2}$ : 逆王で空気が流れた場合の軸流タービン動

翼入口側から流出する空気流絶対速度

$d:$ 水弁没水深 (水弁室水面に没水している鉛 直管空気通過口までの深さ)

$O:$ 空気流調整装置開度 (\%)

$N:$ タービンおよび発電機回転数 $(\mathrm{rpm})$

$\triangle P_{T}:$ タービン出入口差圧 $(\mathrm{kPa})$

$\triangle P_{T^{+}}{ }^{*}$ : 正圧側タービン出入口差压 $(\mathrm{kPa})$

$\Delta P_{T}{ }^{-}$: 負圧側タービン出入口差圧 $(\mathrm{kPa})$

$Q:$ 質量流量 $(\mathrm{kg} / \mathrm{s})$

$u:$ タービンの周速

Wo：逆圧時に軸流夕ービン動翼出口側から流入 する逆方向流れの空気流相対速度

$W_{1}$ : 逆圧で始動時や空気流絶対速度が大きな場 合に軸流夕ービン動翼内を流孔る空気流相対 速度

W2 : 逆圧で空気が流れた場合の軸流夕ービン動翼

入口側から流出する空気流相刘速度

$W_{G}:$ 発電機出力 $(\mathrm{kW})$

$W_{\text {Gin }}$ : 発電機入力 $(\mathrm{kW})$

$W_{T}:$ タービン出力 $(\mathrm{kW})$

$W_{\text {Tn }}$ : タービン入力エネルギー $(\mathrm{kW})$

$\alpha_{0}$ : 流量係数（流路損失含む）

$\rho_{\text {air }}:$ 空気密度 $\left(1.205 \mathrm{~kg} / \mathrm{m}^{3}\right.$ at $\left.20^{\circ} \mathrm{C}\right)$

$\eta_{\mathrm{T}}:$ タービン効率

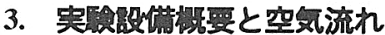

本実験没備は，福島県原町市にある東北電力原町火力 発電所南防波堤先端に設置され，1996 年から実海域実 験を開始した。その概略構成は，図 1 に示した通りで， 波エネルギーを空気エネルギーに変換する空気室 (全4 室），空気エネルギー (空気流)を整流する水弁（水弁 室），整流した空気エネルギ一を集約する集合ダクト， タービンおよび発電機，発電に必要な機器・装置類等を 組み込んだ波力発電ケーソンと呼ばれるコンクリート構 造物を防波堤に搭載した，沿岸固定式振動水柱型に属す る波力発電システムである。

実験設備と $6 \mathrm{kV}$ 配電線とは，陸上側にある観賏所の 系統連系装置により連系され, 波・空気空圧力・発電出 力等の計測デー夕は観測所に伝送されパソコンにより解 析処理される.なお，今回使用した波力発電ケーソンと タービン外観について図 2 およひ図3に，ケーソン・タ 一ビン・発電機の仕様について表 1 および表 2 に示す。

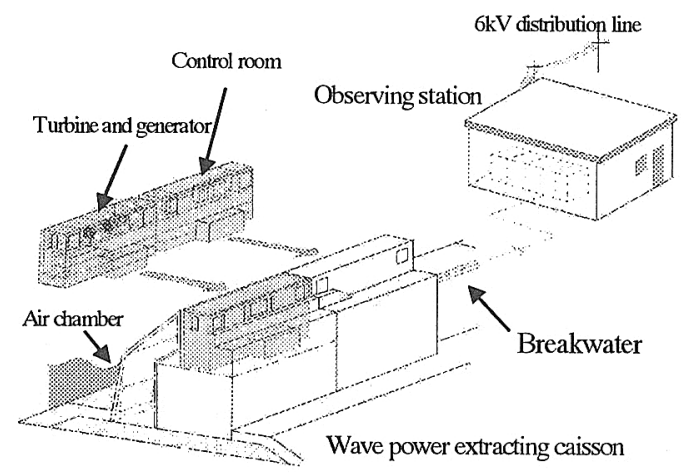

Fig. 1 Overall composition of wave power generation system

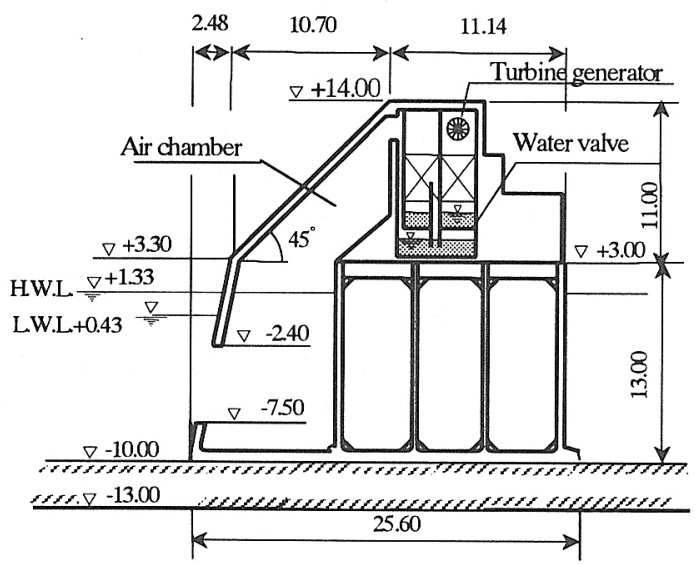

Fig 2 Wave powerextracting caisson. 
Table 1 Specifications of wave power extracting caisson.

\begin{tabular}{|l|c|}
\hline Design wave height & $7.3 \mathrm{~m}$, Max. $11.2 \mathrm{~m}$ \\
\hline Design wave period & $16.0 \mathrm{~s}$ \\
\hline Dimensions of caisson & $24.32^{(\mathrm{W})} \times 240^{(\mathrm{H})} \times 20.85^{(\mathrm{L})} \mathrm{m}$ \\
\hline Number of caissons & 2 (Four air chamber) \\
\hline
\end{tabular}

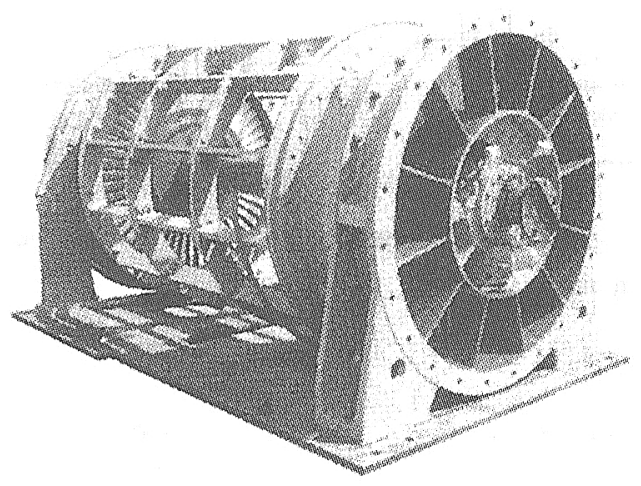

Fig, 3 Tandem type axial-flow turbine.

Table 2 Specifications of turbine and generator.

\begin{tabular}{|c|c|c|}
\hline Tubine: & Tandem type: & turbine \\
\hline Rated speed & $500 \mathrm{mpm}$ & 1000 rpm \\
\hline Rated power & \multicolumn{2}{|c|}{$1445 \mathrm{~kW}, \operatorname{Max} 3625 \mathrm{~kW}$} \\
\hline Stator blade & \multicolumn{2}{|c|}{36 for one stator } \\
\hline Channel height & \multicolumn{2}{|c|}{$241 \mathrm{~mm}$} \\
\hline Rotor blade & \multicolumn{2}{|c|}{53 for one rotor } \\
\hline Channel height & \multicolumn{2}{|c|}{$274 \mathrm{~mm}$} \\
\hline Diameter of rotor & \multicolumn{2}{|c|}{$\operatorname{Max} 1517 \mathrm{~mm}$} \\
\hline Blade materials & \multicolumn{2}{|c|}{ Aluminum alloy } \\
\hline Weight & \multicolumn{2}{|c|}{$11970 \mathrm{~kg}$} \\
\hline 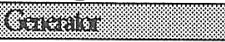 & \multicolumn{2}{|c|}{ Three-phase induction generator } \\
\hline Output voltage & \multicolumn{2}{|c|}{$400 \mathrm{~V}$} \\
\hline Synchronouns speed & 500 rpm & 1000 pm \\
\hline Rated output & $65 \mathrm{~kW}$ & $130 \mathrm{~kW}$ \\
\hline Number of poles & 12 & 6 \\
\hline Connection & $\triangle$ & $Y$ \\
\hline Frequency & \multicolumn{2}{|c|}{$50 \mathrm{~Hz}$} \\
\hline Weight & \multicolumn{2}{|c|}{$3100 \mathrm{~kg}$} \\
\hline
\end{tabular}

ここで, 波力発電ケーソンは，防波堤としての機能を 果たす必要があるため，堤体の安定性・消波効果・施工 面等から形状・寸法に制約を受け，図2に示した形状・ 寸法となっており，最大 $11.2 \mathrm{~m}$ 波に耐えうる設計とな っている。この波力発電ケーソンに組み込まれている水 弁（水弁室）と集合ダクトおよび夕ービンは，寄せ波で 大気压より高王となる空気エネルギーを取り出す正圧側
と，引き波で大気圧より低圧となる空気エネルギ一を取 り出す負圧側に分かれている。

空気室とタービンのマッチングについて述べると，有 義波の波高 $4 \mathrm{~m}$, 周期 $10.55 \mathrm{~s}$ で平均発電出力 $130 \mathrm{~kW}$ 力 得られる設計になっているが，実験海域で 4 mの高い波 の発生頻度は極めて低く，1 $\mathrm{m}$ 以下の波力外とんどであ る.このため，発生頻度の多い $1 \mathrm{~m}$ 前後の波でも十分発 電可能なようにタービン・発電機の回転数は，低波浪時 側の $500 \mathrm{~mm}$ と高波浪時側の $1000 \mathrm{mpm}$ に切替か行える ようにしてある。また，空気室水面面積と夕ービンス口 一ト面積の比（開口比）は，1/600である。

発電機は，経済性を考慮して誘導発電機を採用してお り，低波浪時側が 12 極で $65 \mathrm{~kW}$ 定格，高波浪時側が 6 極 $130 \mathrm{~kW}$ 定格で，タービンと同一軸上に連結されてい る.

次に，本害験設備で水弁を使用し運転する通常時空気 流れを図 $4^{(3)}$ に示す。ここで，寄せ波によって空気室 （air chamber）内の水面が上昇するため，空気室内の空 気が大気圧より高圧に厈縮される。

この圧縮空気が压力の低い大気側向かって, 正王水 弁 (正圧水弁室) $\rightarrow$ 正圧集合ダクト $\rightarrow$ タービン $\rightarrow$ 大気へ と流れる。この時, 負圧水弁側の水面は, 負圧水弁室内 の空気の圧力上昇によって押し下げられ，その圧力に相 当する水頭差分の水が負圧集合ダクト側へ押し上げられ， タービンへの空気流路ができず逆止弁として機能する。

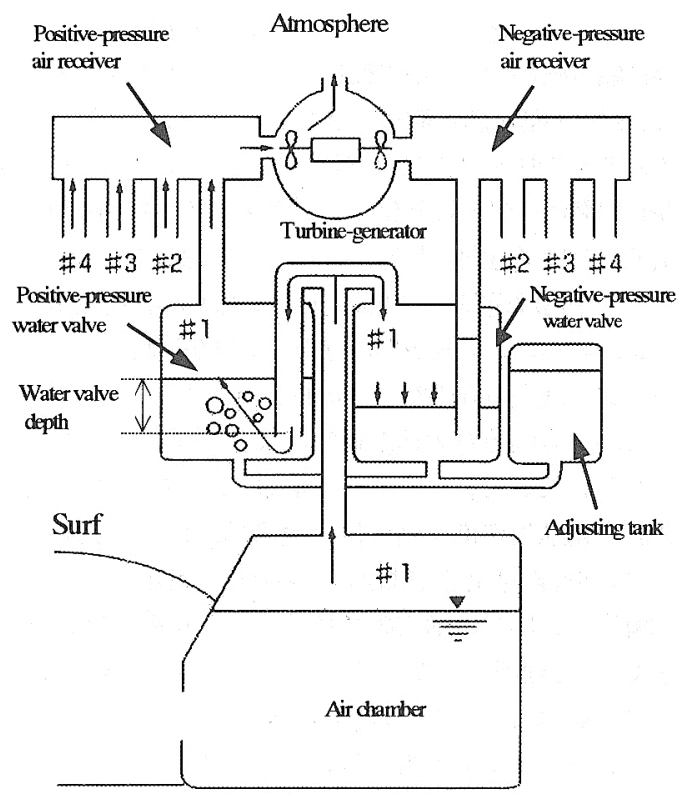

Fig. 4 Airflows of wave power generation system. 
引き波の場合には寄せ波とは逆に，大気側から負圧側 のタービン $\rightarrow$ 負圧集合ダクト $\rightarrow$ 負圧水弁 $\rightarrow$ 空気室へと空 気が流れ，正圧水弁側が逆止弁として機能する.

この実験設㖮では，正圧および負厈水弁の水をポンプ で排水することによって, 水弁が無い状態, つまり整流 弁を持たない状態溶易に実現できる.このため, タン デム配置した軸流タービンに対して, 寄せ波・引き波の 双方向の空気流を整流した形で一方向から流す験と, 整流せず双方向から流す夷験が可能となる.

図5は, 水弁使用時の軸流夕ービンへの空気流れを示 したものである. 水弁が完全に整流弁の機能を果たした 場合，寄せ波の空気は，図中左側の正圧集合ダクト

(Positive pressure airreceiver) から正圧側タービンの静 翼 $\rightarrow$ 動翼 $\rightarrow$ 大気と流れ, 右側の負圧側タービンには水弁 の逆止弁効果により空気は流れない.

引き波時の空気は, 大気側から図中右側の負圧側夕ー ビンの静翼 $\rightarrow$ 動翼 $\rightarrow$ 負圧集合ダクト (Negative pressure airreceiver）と流れ，水弁が完全に整流弁の機能を果た した場合，正圧側タービンには寄せ波時と同様に逆止弁 効果により空気は流れない。

このように，水弁を使用し完全に空気か整流された状 態においては, タンデム型軸流タービンを通過する空気 流は, 常にタービン静翼側から流入し動翼に流れる一般 的な軸流夕ービンの空気流れと同様になる.

これに対して図6は, 水弁室の水を空にし, 水弁か無 い状態で運転した場合の寄せ波時空気流れを示したもの である.この場合, 正圧側タービンには水弁使用時と同 様に順方向から空気が流れるが, 差圧の大きさによって は, 眓中右側の負圧側タービンにも空気が流れようとす ると考えられる.この時の空気流れは, タービン動翼側 から静翼側一の流れとなり, 軸流夕ービンの一般的な空 気流れとは逆方向となる. なお, 引き波時には, 図に示 した知印とは逆向きの空気流れとなるため, 負圧側夕一 ビンに対して大気側から順方向の空気が流れ，正圧側夕 一ビンには逆方向の空気が流れようとする.

この逆方向流れの速度線図例は, 図7に示したよう になる.ここで, タービンの周速は, 電力系統に連系 され発電状態にある時には, 発電機同期速度と同じく なり，低波浪時側ではほぼ500rpm一定となる.

眓7において, 通常の系統連系した状態では, 絶対 速度 $\mathrm{C}_{0}$ で軸流方向から流入する逆方向空気流は, 夕 一ビン動翼に対して相対速度 $\mathrm{W}_{0}$ で流入する空気流と なり, タービンの回転方向にブレーキ力として作用す ると考えられが, 実海域では波の状況によって, 流入 する空気流の流速・流量が絶えず変化している.

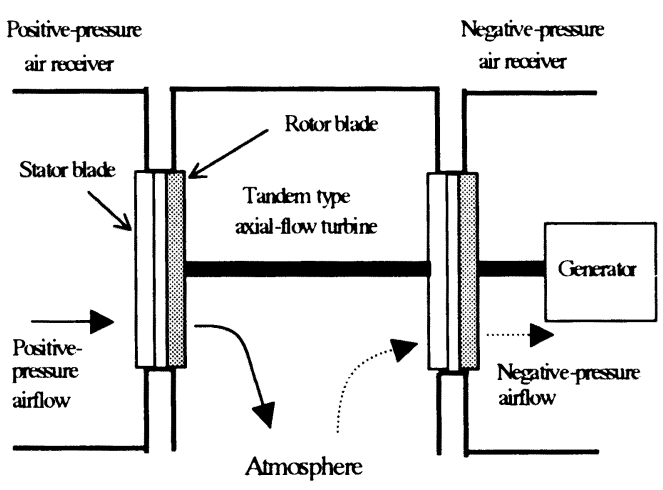

Fig. 5 Airflows into tandem type axial-flow turbine (using rectifying valve).

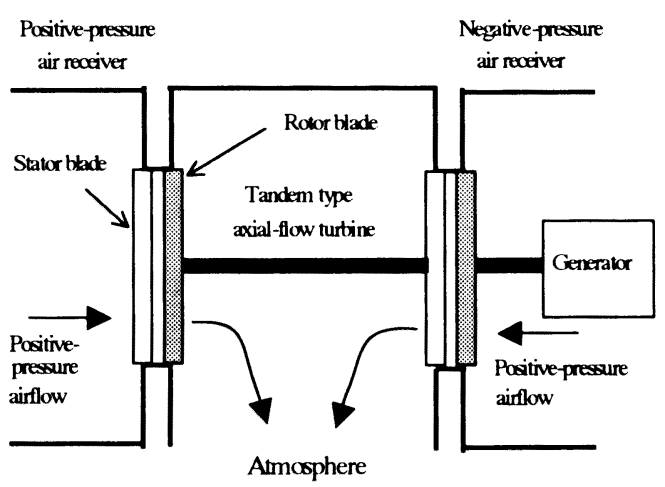

Fig. 6 Airflows into tandem type axial-flow turbine (not using redifying valve).

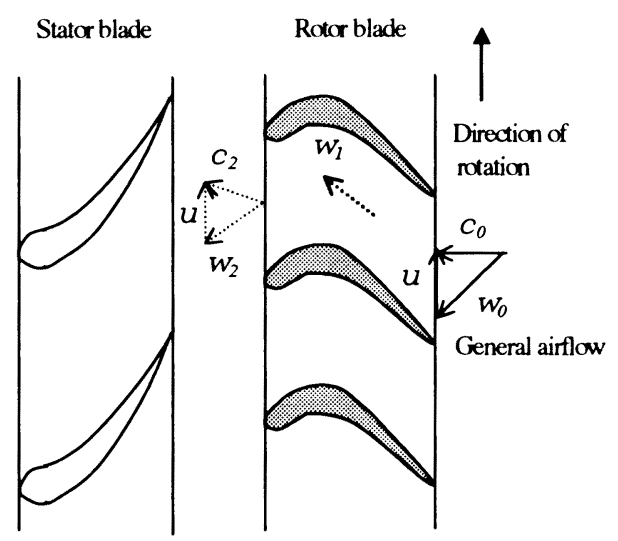

Fig. 7 Blade arrangement and velocity diagram of axial-flow turbine at reverse direction airflow. 
このため, タービン起動時や流入する空気流の絶対 速度が著しく速い場合には，空気流の相対速度 $\mathrm{W}_{0}$ は 絶対速度 $\mathrm{c}_{0}$ 方向（軸流方向）に近づき $\mathrm{W}_{1}$ のように夕 一ビン動翼に翼面に沿って流れ，ブレーキ力が働かな い状態が期待できる.

したがって, 実海域で連続䡣した結果から逆方向空 気流によるブレーキ損失が小さく, タービン効率がウエ ルズタービンより高効率であれば，整流弁を使用しなく ともタンデム型軸流タービンは波力発電に有効なタービ ンと考えられる.

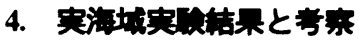

本実験設備は，波浪状況に応じた運転切替が行える 設備となっているが, 実験海域における波力発電ケ一 ソン前の波は，ほとんどが $1 \mathrm{~m}$ 以下の波で，台風接近 時においても有義波波高は, 最大 $2 \mathrm{~m}$ 程度であった. このため, 今回の実海域実験は，ほとんど高波浪時側 では行えず低波浪側の 500 rpm で実施している.

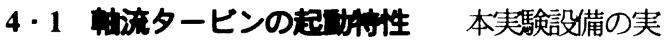
海域夷験デー夕の計湘迈理は，発電機の並列を条件に自 動的に行われる.このため, 発電機の同期速度に達する までは, 各種データが計測されない。そこで，タービン の起動特性を確認するため，一時的にオシロを接続して， タービン起動時の正圧および負圧側タービン出入口差圧 と回車数変化等の起動特性に関する実験を行った。

この実験結果を図 8 に示すが, 実験を行った時の波 力発電ケーソン前での有義波波高は $0.91 \mathrm{~m}$, 周期が $6.3 \mathrm{~s}$, 水弁没水深は $10 \mathrm{~cm}$, 夕ービン・発電機の運転回転数が 500 rpm である.

図8において，正圧および負圧側タービンの差圧は， 寄せ波・引き波によって生じるものであるが, タービン に対して順方向流れとなる方向をプラス側としている.

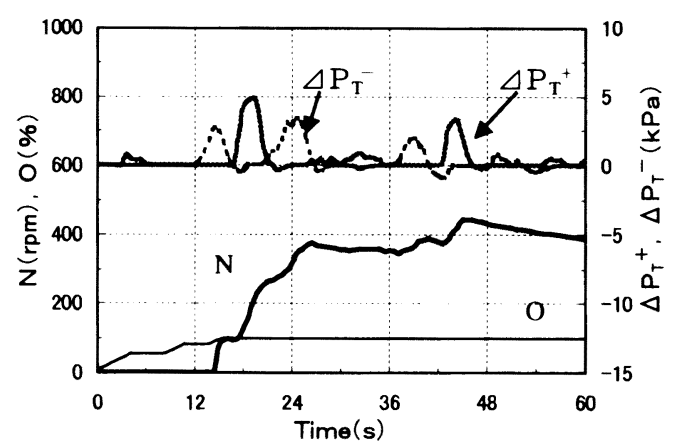

Fig 8 Starting characteristics of Tandem type axial flow turbine.
この差圧によってタービンに空気が流れるため, 差圧の 大きさの違いは空気流量の違いを表している.

図8を見ると, 差圧が $1 \mathrm{kPa}$ 程度では夕ービンの回転 数にほとんど影響は見られないが, 差圧が $2 \mathrm{kPa}$ を越え た場合, タービンの回転数が差圧の上昇に合わせ急上昇 しているのがわかる. これに対して, 差圧の下降側では 上昇側に比べ緩やかな回転降下となっている。これは, タービン働く慣牲力によるものだと考えられる.

タービンの回転数は, 起動から $25 \mathrm{~s}$ 経過したあたりで 400 rpm 付近まで達しているが，その後暫く大きな波が 来なかったため, 差圧がほとんど得られず, 暫くは発電 機並列条件の 500 pm には達しなかったが, 起動後約 5 分経過したところで差圧が $6 \mathrm{kPa}$ に上昇する過程で並 列した.このデー夕において，並列まで5分の時間を要 したのは, 波が $1 \mathrm{~m}$ 以下と低い 状況で水弁の没水深を深 めに設定していたため, 水弁によって生じる圧力損失か らタービンを $500 \mathrm{pm}$ まで回転させる十分な圧力が得ら れなかったからである. 実験期間中の運転実績では, 水 弁を使用しない場合や有義波の波高が $1 \mathrm{~m}$ を越える状況 では, 発電機並列に要する時間は短くなり， $1.5 \mathrm{~m}$ を越 える波の場合で 30 s以下のものも見られた。

今回の実験結果とウエルズタービンの実海域夷験結果 との比較は, 発電システムの機器構成の違いや波浪状況 が異なるために単純に行えないが, 少なくとも $1 \mathrm{~m}$ 程度 の低い波で比較的容易に発電可能になる点とウエルズタ 一ビンような失速は一度も見られなかった点から，軸流 タービンの低波浪海域での優位性か認められる.

\section{$4 \cdot 2$ 逆方向空気流による諳 タンデム型軸流夕} 一ビンにおける逆方向空気流の影響を確認するため, 水 弁（整流弁）の有無による入射波波エネルギーに対する 平均発電出力の違いを表したものか図 9 (3) である.

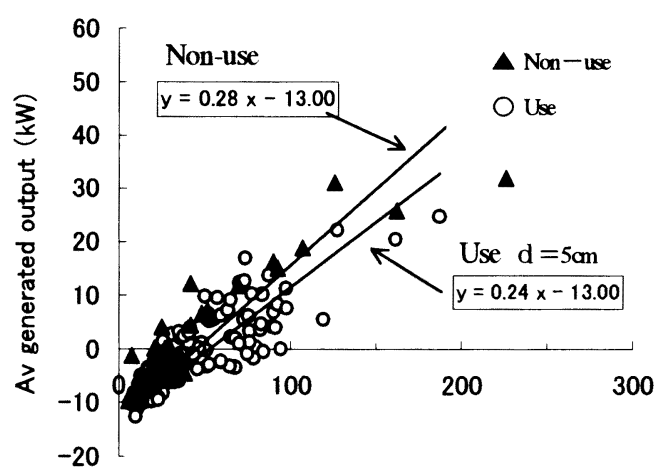

Av incident wave power ( $\mathrm{kW})$

Fig. 9 Difference between use and non-use of water valve (rectifying valve). 
この実験は，波浪状況が近い日を選び，水弁以外の人 為的に変更可能な条件は同条件にし, 空気室数が半分, 運転回転数を低速側 $500 \mathrm{~mm}$ としている. 水弁使用側の 水弁没水深は, 深くすると水頭差による圧力損失でシス テム総合効率か低下することと, 浅くすると整流弁とし ての機能を失う恐れがあるため，運転実績に基づいて， 実験日の波浪状況で水弁の機能か維持され，発電システ ムの総合効率が高効率となる最商設定の $5 \mathrm{~cm}$ としてい る.

ここで, 図 9 に併記した近似式の傾きは, 入力エネル ギーに対する出力の関係にあることから，本実験設備の 総合効率 (平均) を示していて, 近似式の切片に相当す る- $13 \mathrm{~kW}$ は誘導発電機の励加磁損失等損失である.

図 9 から，水弁を使用せず軸流タービンに逆方向空 気流が流れた場合と，水弁を使用して最適運転を行っ た場合とでは総合効率に大きな差を生じていない.こ のように発電出力から見た結果から，本実験設備で使 用したタンデム型軸流タービンは, 波力発電において 水弁等の整流弁が無くとも逆方向空気流を含む往復空 気流で十分に発電可能であり, 発電出力の著しい低下 も見られなかった。

次にタービン自体が逆方向空気流を含む往復空気流 でどのように機能しているかを確認するために，以下 に示す(1)〜(3)の実験を行った。

（1）水弁を使用状態にして，その深さを $5 \mathrm{~cm}$ と浅 く高効率運転し, タンデム型軸流タービンの一 方へ流れる空気を鋼板製の空気流調整装置で遮 断し，片側タービンのみに空気流を流す.

（2）水弁の条件は(1)と同条件にして，空気流調整 装置を全開にしてタンデム型軸流タービン双方 へ水弁で整流した空気流を流す。

（3）水弁は使用せず，タンデム型軸流タービン双 方へ整流していない往復空気流を流す。

この実験結果については，本実験設備の構造面等の 制約上卜ルク計測が行われていなかった点と，運転上 の指標的な位置づけで取り付けされた回転数計では精 度が低い点から, タービン出入口差圧との関係から評 価することにした。

実験（1）の結果として, タービン出入口差圧と発 電出力の関係を表したものを図 10 に示す.ここで, タービン出入口差圧の符号は, 空気が静翼側から動翼 側へ流れる順方向流れ（静翼入口一動翼出口圧力）の 圧力をプラスとしているため, マイナス側は動翼出口 側から空気流が流入する，いわゆる逆圧の状態を示し ている.

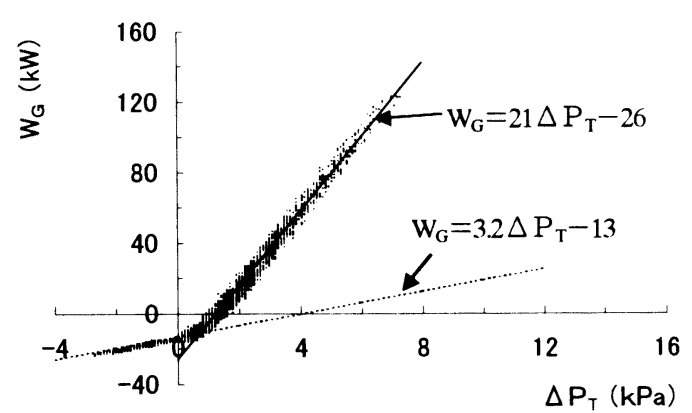

Fig.10 Relation between differential pressure $\left(\Delta P_{T}\right)$ and generated output $\left(\mathrm{W}_{\mathrm{G}}\right)$ at single turbine blade.

図 10 ○於いて，整流弁が機械式弁であれば逆圧状 態が生じるとは考えにくいが, 水弁の場合, 図8の差 圧波形にも現れているように，時には逆圧か防止され ない現象が起きている.このため, 併記してある近似 式で示されるように二通りの傾向が見られる．逆圧時 の近似式 $\mathrm{W}_{\mathrm{G}}=3.2 \Delta \mathrm{P}_{\mathrm{T}}-13$ の傾きから逆圧で生じる 損失が，差圧 $1 \mathrm{kPa}$ あたり $3.2 \mathrm{~kW}$ と小さいことがわか る. なお, 両近似式の切片に相当する値は, 誘導発電 機の励磁損失や. 同期速度を維持するために必要な動 力損失で, $500 \mathrm{rpm}$ 運転時の固定損失と考えられる.

次に，実験（2）の結果を図 11 に示す.この実験 ケースは，基本的には図 5 に示した空気流れとなり， 正圧・負圧側の両タービンに水弁で整流された空気が 流れるが, 実験（1）の結果から逆圧の影響を若干は 受けている. しかしながら, タンデム型の軸流タービ ンは, 同一軸上に二つのタービン翼が取り付けられて いるため，逆圧の影響を分離できない，そこで，実験 （1）の結果から逆圧の影響が少ないことは明らかな ので，ここでは，各計測時間における差圧の比較を行 い, 圧力值の高い側のタービンを稼動側タービンと考 え,この稼動側タービンの差圧と発電出力の関係で表 している.したがって, 図 11 には時折発生する逆圧 時の損失が含まれたものとなっている.

図 11 を見ると，図 10 に比べ波浪状況が良好であ ったことから差圧が $10 \mathrm{kPa}$ を越える範囲まであり, 差 圧の高い領域で幾らか飽和僋向を示して, 発電出力の 近似式の傾きは, 図 10 より若干小さい 19.2 となっ ている.

最後に，実験（3）の結果を図 12 に示すが，この 䒠験ケースは, 水弁が無いために稼動側タービンと反 刘側のタービンは，常に逆圧の影響を受けている。こ のため, 差圧に対する発電出力は, 図 11 の時と同じ 
く稼動側タービンに逆圧による損失を含めた形で示し てある。

図 12 の計測デー夕は, 図 11 のデータと比較して ばらつきは少ない. 図 12 2では, 水弁を使用しないた め, どちらか一方のタービンが常に逆圧状態となるが, 図 11 では, 水弁を使用しているため, 常時は逆圧と ならないが, 水弁の水面変化と差圧の大きさ等によっ ては, 逆圧を生じることがある.このため, 時折生じ る逆圧の影響がばらつきとして現れていると推定され $ろ^{(4)}$.

常に逆圧が生じた場合，その損失を実験（1）の結 果から $\mathrm{W}_{0}=3.2 \Delta \mathrm{P}_{\mathrm{T}}-13$ と仮定し, 逆圧の影響を受 けない稼動側タービンの発電出力が, 図 11 と図 12 が波浪状況が近いため同じと考え， $\mathrm{W}_{\mathrm{g}}=19.2 \Delta \mathrm{P}_{\mathrm{T}}$ 26 と仮定すると, 図 12 の損失を含んだトータル発 電出力の推定式は, $\mathrm{W}_{\mathrm{G}}=19.2 \Delta \mathrm{P}_{\mathrm{T}}-26-\left(3.2 \Delta \mathrm{P}_{\mathrm{T}}\right.$ 13） $=16 \Delta P_{T}-13$ で表される. この推定式を図 12 に併記して見ると，推定式が各計測点における差圧と 発電出力の関係と極めて良い一致を示している.

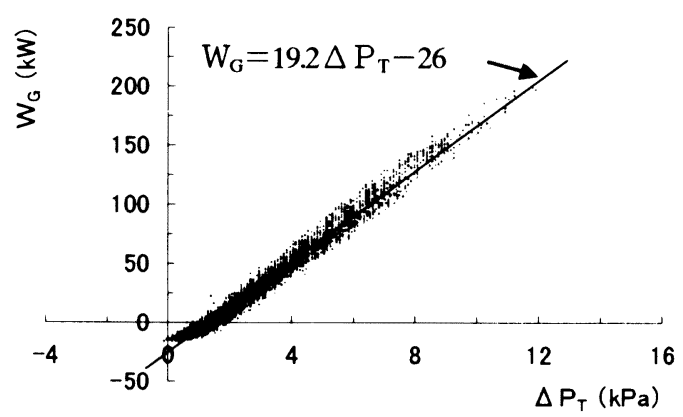

Fig.11 Relation between differential pressure $\left(\Delta P_{T}\right)$ and generated output $\left(W_{G}\right)$ at tandem turbine blade.

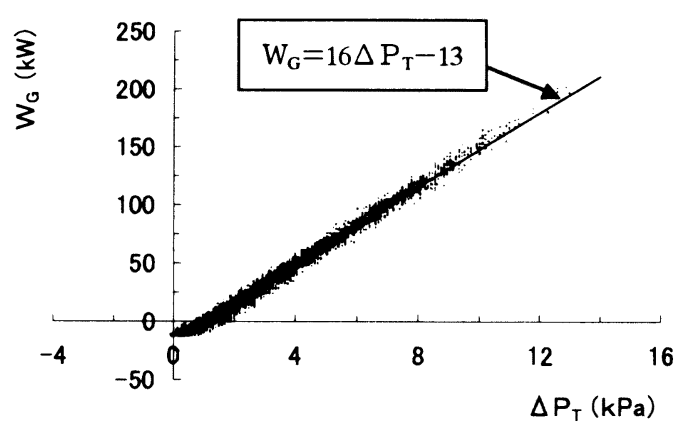

Fig.12 Relation between differential pressure $\left(\Delta P_{T}\right)$ and generated output $\left(W_{G}\right)$ at tandem turbine blade, non water valve.
この推定式と図 11 の近似式の比較から，切片とな る固定損失差を考えると，差圧が低い領域では水弁が 無い方が有利であると考えられる.

水弁がない状態での夕ービン効率は, 計測装置・構 造等の問題から以下の式 (1) 〜 (5) を適用し, 発 電出力は逆圧分の補正を行い求めることとした.

本実験設備におけるタービンへの流路がオリフィス と同様な構造であるので, タービン出入口の差圧から 流量Qは式（1）(5)によって表される.

$$
\mathrm{Q}=\alpha_{0} A_{T} \sqrt{2 \rho_{\text {air }} \Delta P_{T} \times 10^{3}}
$$

この時のタービンへの入力エネルギー $\mathrm{W}_{\text {Tin }}$ とタービ ン出力 $\mathrm{W}_{\mathrm{T}}$ は, 式 (2) および式 (3) で表される.

$$
\begin{aligned}
& W_{\text {Tin }}=\frac{\mathrm{Q}}{\rho_{\text {air }}} \Delta P_{T} \\
& W_{T}=W_{\text {Tin }} \eta_{T}
\end{aligned}
$$

また，発電機の入力エネルギー $W_{G_{n}}$ は，発電機工場 試験の結果から発電出力 $\mathrm{W}_{\mathrm{G}}$ と式 (4) の関係にある.

$$
W_{\text {Gin }}=1.02 W_{G}+5.8
$$

ここで, タービン・発電機の軸受は, アンギュラ玉 軸受および円筒ころ軸受を使用しているためにその摩 擦係数は $1.0 \times 10^{3}$ 程度と小さく, 軸受の摩擦損失は無 視できる程度である.

したがって, タービンの効率 $\eta_{\mathrm{T}}$ は次式 (5) で表 すことができる. 但し，このタービン効率には形状損 失・二次損失等損失 ${ }^{(6)}$ が含まれる.

$$
\eta_{T}=\frac{W_{T}}{W_{T i n}}=\frac{W_{G i n}}{W_{T i n}}
$$

四 13 に, 求めたタービン効率とタービン出入口差 圧との関係を示す.ここで, 差圧が $3.5 \mathrm{kPa}$ 以上の場 合，多少ばらつきはあるが効率は概ね 30〜60\%の範囲 にあり, 差圧が $3.5 \mathrm{kPa}$ 末満では，非常にばらつきが 大きいが, 効率 $80 \%$ を越えるものも見られる. 全計測 データの平均効率で $38 \%$, 波エネルギーが極めて小さ く差圧がゼロになる点を除けば $47 \%$ となっている.

計測点全体のばらつきの傾向は, 差圧の上昇側と下 降側に分かれており，下降側の方が効率は高目で変化 している. 差圧が低い領域において効率が高くなって いる点については, 稼動側でない反対側夕ービンの損 失の影響や非定常流における流量係数・流路損失の変 化等が複雑に影響していものと考えられる. 


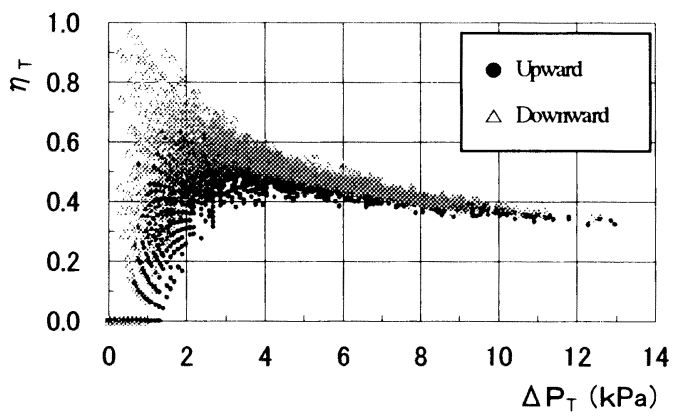

Fig.13 Relation between differential pressure $\left(\Delta \mathrm{P}_{\mathrm{T}}\right)$ and axial-flow turbine efficiency $\left(\eta_{\mathrm{T}}\right)$ at tandem turbine blade, non water valve.

この結果から，今回使用した軸流タービンは，差圧 が低い領域で高い夕ービン効率を示しており，低波浪 状況が多い海域へ有利なタービンであると考えられる. なお，本論文に示した各計測デー夕はいずれも実験 設備における空気室等の数が半分になる波力発電ケー ソンの運転函数を 1 函で運転した時のデータである.

\section{5. まとめ}

今回，タンデム型軸流タービンを採用した波力発電 実験設備による実海域実験の結果から，以下のような ことが明らかになった。

（1）実験に使用した軸流タービンは，実海域において 有義波波高 $1 \mathrm{~m}$ 程度の低い波でも，タービン出入口差圧 が $6 \mathrm{kPa}$ 以上あれば, タービン回転数は比較的容易に 発電可能な $500 \mathrm{pm}$ に達し, ウエルズタービンに見られ た失速領域も見られなかった.

（2）逆圧時の本タンデム型軸流夕ービンの損失は, 差圧 $1 \mathrm{kPa}$ あたり $3.2 \mathrm{~kW}$ 小さなものであった.

（3）水弁を使用せず逆圧を受ける状態でもタンデム 型軸流夕ービンで発電可能であり, 本実験海域での平 均効率が 37\%, 波エネルギーが非常に小さい差圧ゼロ 点を除けば 47\%となり, ウエルズタービンの実海域平 均効率が最大 $45 \%$ 前後 ${ }^{(7)} \sim(8)$ と比較して, ほほ同等 であった。
（4）軸流タービンは，今回の実験結果から $1 \mathrm{~m}$ 以下 の低波浪時（低差圧）領域で容易に起動でき, 低差圧 でタービン効率が高効率な点を考えると, 常時 $1 \mathrm{~m}$ 前 後の波が存在し, 台風襲来時以外に $2 \mathrm{~m}$ を越える高い 波がめったに発生しない太平洋沿岸のような低波浪海 域に有利なタービンであると考えられる.

（5）水弁は完全に逆圧を防止できない点, 水弁を使 用しなくとも本タンデム型軸流夕ービンで発電システ ムの総合効率が同等の 28\%が得られる点, 水弁の水位 調整のために本実験設備では最大 $3.7 \mathrm{kWh} \times 4$ 台 $15 \mathrm{kWh}$ のボンブ動力を消費する点から，水弁は致命的 な破損はないが，整流弁としてはあまり期待はできな い.

以上に述べた実海域㬰験から得られた知見は，今後 の波力発電実用化に向けた研究への活用が期待される.

\section{文献}

（1）土木学会・エネルギ一土木委員会, 波エネルギー利用技術の 現状と将来展望, (1990)，38-39, 土木学会.

（2）中島・潮昌，港湾技研資料，No.958，（2000），3，港湾技術 振興会.

（3）植木・菊地・吉目木, 波力発電システムの実用化に関寸る研 究, 日本応用磁気学会誌, 26-4(2002)，693-702.

（4）植木 - 石澤・吉目木・菊地, 水弁集約式波力発電システムの 発電出力に関する検討, 日本応用磁気学会誌，25，（2001） 995-998.

（5）馬場秋次郎，機械工学必募，（1986），762, 三省堂.

（6）三輪光砂，ガスターービンの基礎と実際，(1991），117，成山 堂書店.

（7）鈴木・荒川・田古里，波力発電用ウエルズタービン性能に及 ほす諸因子の影䈏，回波浪エネルギー利用シンボジウム テキスト，(1987-6)，73-81.

（8）沿岸開発技術セン夕一, 防波堤利用の波力発重に関する研究 報告書，（1992），8-19，㳂岸開発技術センタ一. 